\title{
The effects of methodological limitations in the study of butterfly behavior and demography: a daily study of Vanessa atalanta (Lepidoptera: Nymphalidae) for 22 years
}

\author{
Henry F. Swanson ${ }^{1}$ and Julián Monge-Nájera² ${ }^{2}$ \\ 11531 Norfolk Avenue, Winter Park, FL 32789-5518 USA; sgregory@barton.edu \\ 2 Biologia 15, Universidad de Costa Rica, 2060 San José, Costa Rica. Fax (506)2075550; rtb@biologia.ucr.ac.cr
}

\begin{abstract}
Normally, butterfly behavior and population size are studied intensively for brief periods or occasionally for long periods, not in detail for long periods, producing an incomplete view in both cases. How time limitation affects studies has been unknown for a long time. This paper analyses this problem based on an intensive long term study of Vanessa atalanta (L.) that covered nearly 8000 days, most of them consecutive, for 22 years (April 15, 1977-April 14, 1999), in a subtropical habitat near Orlando, Florida. There is no evidence that ethological studies are affected by their normally brief duration (one year or less), but the analysis of yearly values hid the associations of number of individuals and arrival time with climate. In small areas, isolated population counts lasting less than two weeks are not reliable, according to this study. We found no difference in number of visitors for El Niño years. The daily number of visitors was inversely correlated with temperature and precipitation, but arrival time of the first visitor was positively correlated with both. The number of visitors reaches a peak near the end of Winter. The activity period span is greater than in more seasonal climates. Individuals were active even at $10^{\circ} \mathrm{C}$ and with $9 \mathrm{~m} / \mathrm{s}$ winds. Individuals with fresh wing condition were most common from January to June. There were 82 atypical cases of individuals arriving before 12:00 hr. Aerial interactions were seen whenever there was more than one individual in the site (i.e. $41 \%$ of days, $\mathrm{N}=7634$ total days). Only once in these 22 years was predation seen.
\end{abstract}

Key words: Long term study, population size, daily visitation pattern, Lepidoptera, weather, El Niño, phenology, behavior, methodology.

For economic and logistic reasons, butterfly biology normally is studied by observing a population intensively for short periods (which is satisfactory to solve ethological problems, e.g. Monge-Nájera et al. 1998), or through isolated observations over a long time (e.g. Stekolnikov's 1992 study that spanned more than half a century). The effort closest to a long term intensive study may be the British monitoring system (Pollard et al. 1997), but it also has important methodological limitations (Nielsen and Monge-Nájera 1991). In general, we ignore how the lack of long term intensive studies effects our view of butterfly ecology.

The current view of butterfly population ecology is summarized in the following paragraphs.
Density dependent factors (e.g. hostplants):The importance of specific hostplant species, individuals and even plant parts for population size, distribution and genetic variability is controversial (Thompson 1988, Daily et al. 1991 Goulson et al. 1997) but there is agreement that food abundance is associated with population increases (e.g. Wickman et al. 1990)

Density independent factors: In tropical areas of varying altitude, warmer and moister periods are associated with butterfly population increases, while in temperate areas, warm weather normally produces premature emergence, additional generations, increased breeding success and larger adult populations (Pollard et al. 1997, Wickman et al. 1990, Steiner 1991). 
How butterflies reduce the effect of ecological factors: Butterflies can control density dependent and density independent factors in two ways: (1) locally by behavioral and physiological mechanisms, and (2) ex situ by migration. Behavioral mechanisms include activity pattern coordination with the hostplant's reactions to climate, while physiological adaptations even involve larval monitoring of daylength to control development (Young 1983, Kunte 1997, Nylin 1997).

Migration: Butterfly travelling varies from small changes in microhabitat distribution to long range migration. Migration seems to be genetically determined and relates with lifespan (Baker 1984, Ehrlich 1984). Solar radiation, temperature and wind may (Calvert $e t$ al. 1992, Monge-Nájera et al. 1998) or may not (Frey et al. 1992) help predict the microhabitats where populations concentrate. It seems clear that topography (and the microclimate pattern that topography creates) affect both butterfly population size and biodiversity (Gutiérrez 1997).

Mid-range movements: Mid-range movements are associated with isolated habitat patches that predispose a species to the shifting mosaic metapopulation model (Harrison et al. 1998), with relatively frequent local extinctions and re-establishments. Stepping-stone gene flow is important at least in some metapopulations (Neve et al. 1997, Peterson 1997, Singer and Thomas 1997).

Long-range migrations: Long-rảnge migrations are known in tropical and temperate butterflies, among them the Red Admiral, Vanessa atalanta $\mathrm{L}$., a species that appears to fit the requirements for survival in urban areas (Swanson 1979, Kitahara and Fujii 1997, Srygley et al. 1997, Thomas 1984). It is a widespread nymphalid found in the American continent from central Canada to Guatemala, often in clearings (Bitzer and Shaw 1979, Tuberville et al. 1996).

This paper reports on an intensive (daily) long term study (22 years) of a $V$. atalanta population in a subtropical habitat with emphasis on the association of number of individuals and arrival time with climate.

\section{MATERIALS AND METHODS}

Individual butterfly visitation records (and a qualitative microclimatic classification) were made daily by the senior author in an urban clearing devoid of hostplants in Winter Park,

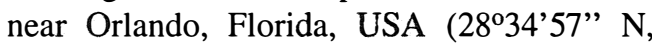
$81^{\circ} 20^{\prime} 04^{\prime \prime} \mathrm{W}$ ) for 22 years (April 15, 1977April 14, 1999: 8035 days). Details of the site and the unusual conditions that allowed daily observations for such a long period appear in Swanson (1998).

Climatic data are from monthly means provided by government databases available in the Internet (http://water.dnr.state.sc.us/climate/May 1999). Besides the inferential statistics presented here, graphs of daily changes in number of visiting butterflies and their arrival time (available in the on-line edition of this journal) were analyzed visually for non-linear associations (Kozlov et al. 1997) but none were found. Non-parametric statistics were used to avoid potential conflict with the less realistic requirements of parametric tests. "Visitation" and "number of daily visitors" are defined as total number of occupants and intruders arriving each day.

\section{RESULTS}

Natural history: Individuals were active even at $10^{\circ} \mathrm{C}$ and with $9 \mathrm{~m} / \mathrm{s}$ winds. Individuals with wings in fresh condition were most common in the first half of year (January-June) when they represented roughly three quarters of the population. Smaller individuals (general impression: no measurements were taken) were seen from late December to late March. There were 82 atypical cases of individuals arriving before $1200 \mathrm{hr}$ (not included in the graphs). Aerial interactions were seen whenever there was more than one individual in the site (i.e. $41 \%$ of days, $\mathrm{N}=7634$ total days, Fig. 1).

A total of 4794 visits were recorded, with an overall attendance rate of $59.5 \%$. During the $2 \mathrm{hr}$ afternoon visit period there were frequently 1-3 individuals in the site, two times there were eight and once (March 15, 1982) there were ten. Only once in these 22 years was 


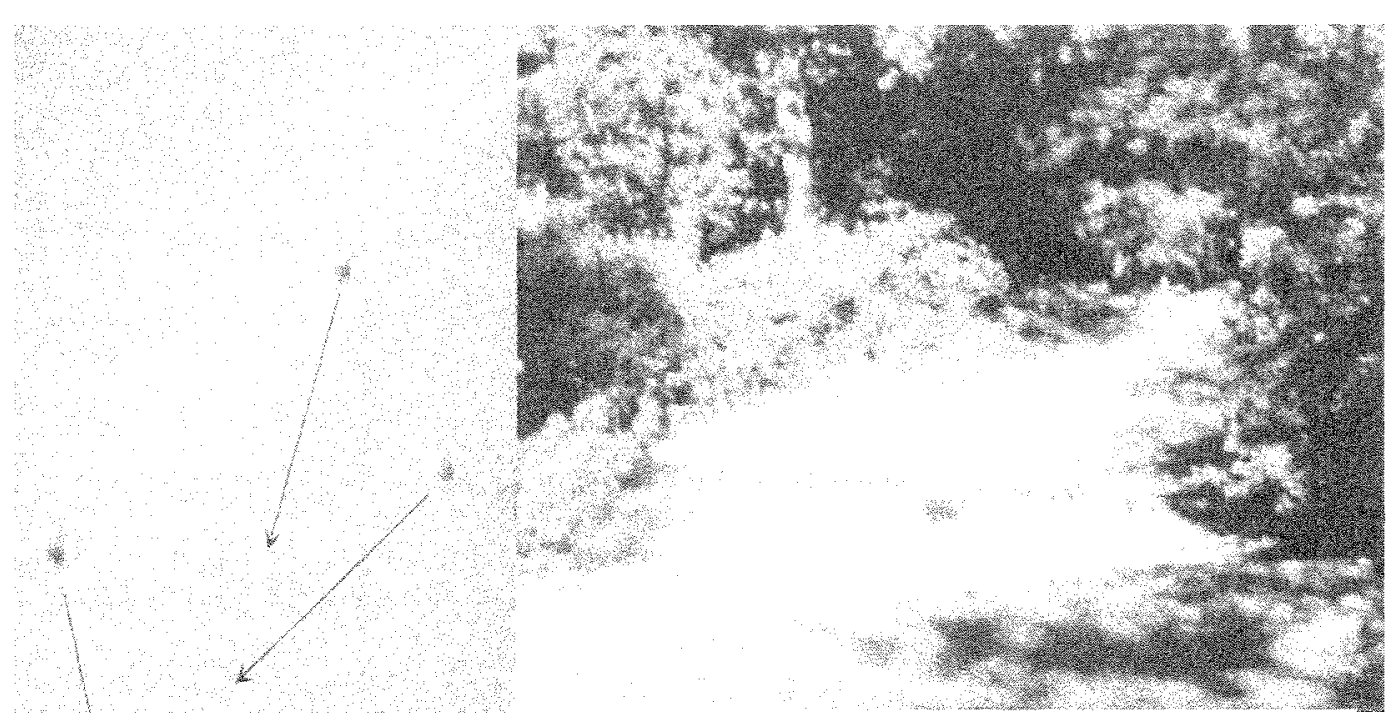

Fig. 1. Aerial interactions of Vanessa atalanta and study site (from a video).
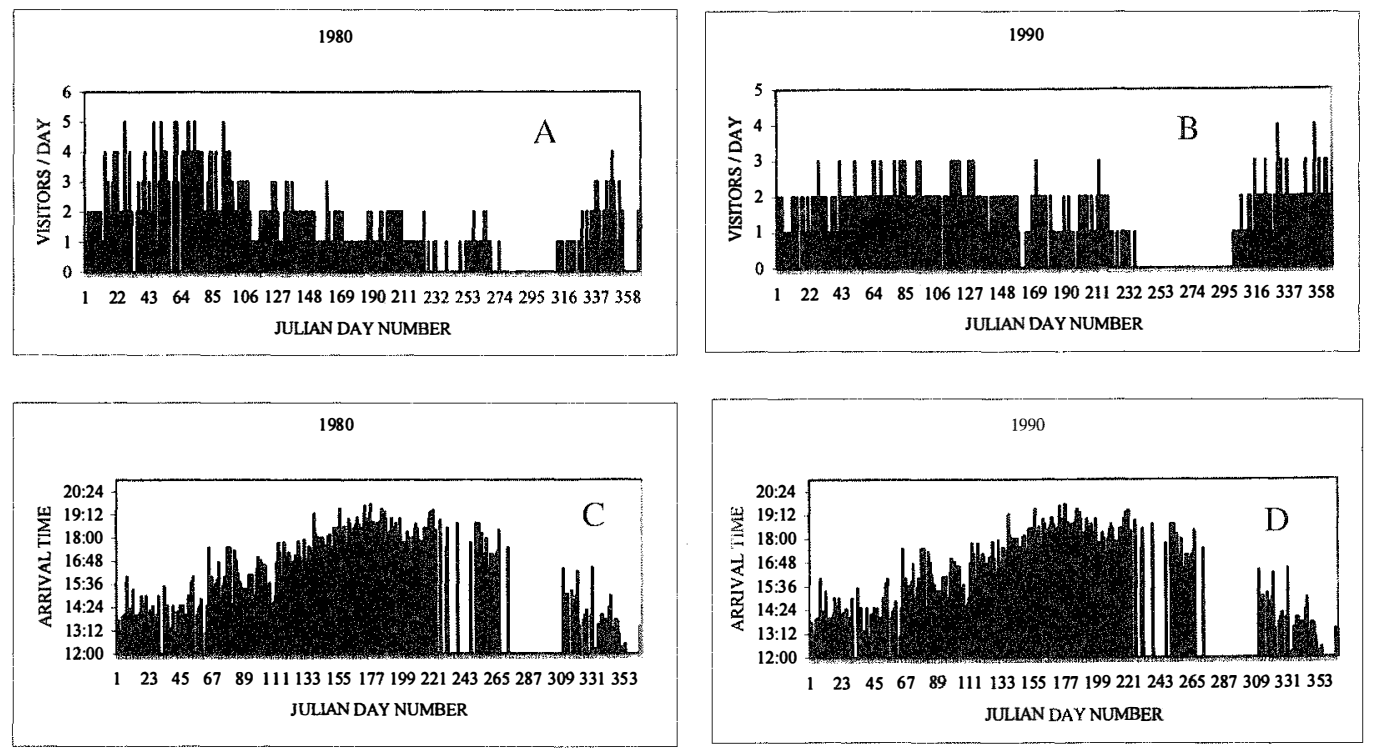

Fig. 2. Two typical visitation and first daily arrival time patterns throughout the year for Vanessa atalanta in a subtropical habitat in Florida. Visitation is shown as number of visitors per day and arrival time of first visitor is given in hours. A.,C. Visitation rate and initial daily arrival times for 1980. B.,D. Visitation rate and initial daily arrival times for 1990. 

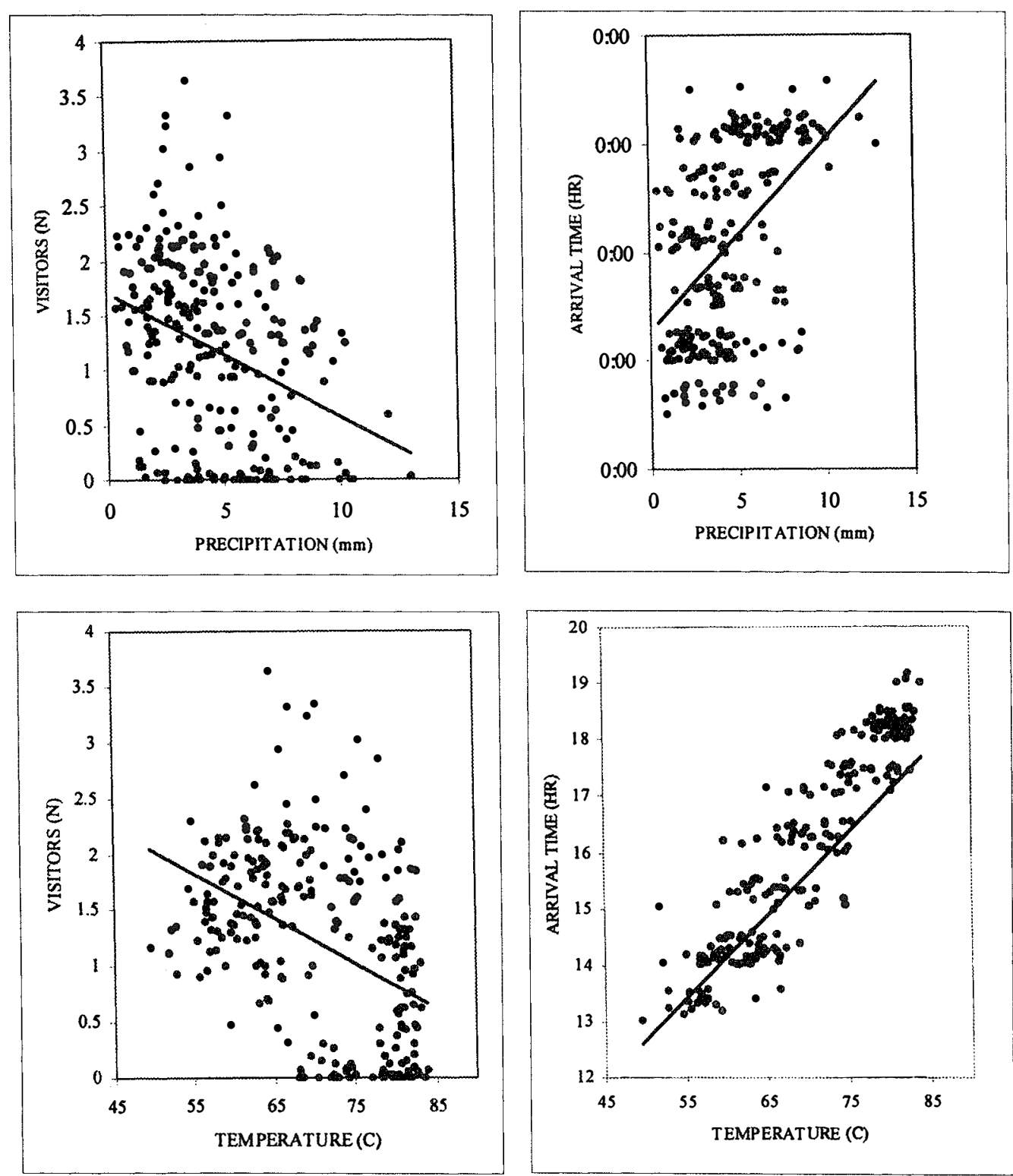

Fig. 3. Relationship of visitation (left) and arrival time (right) of Vanessa atalanta with precipitation (above) and temperature in a subtropical habitat (statistical values in text). 

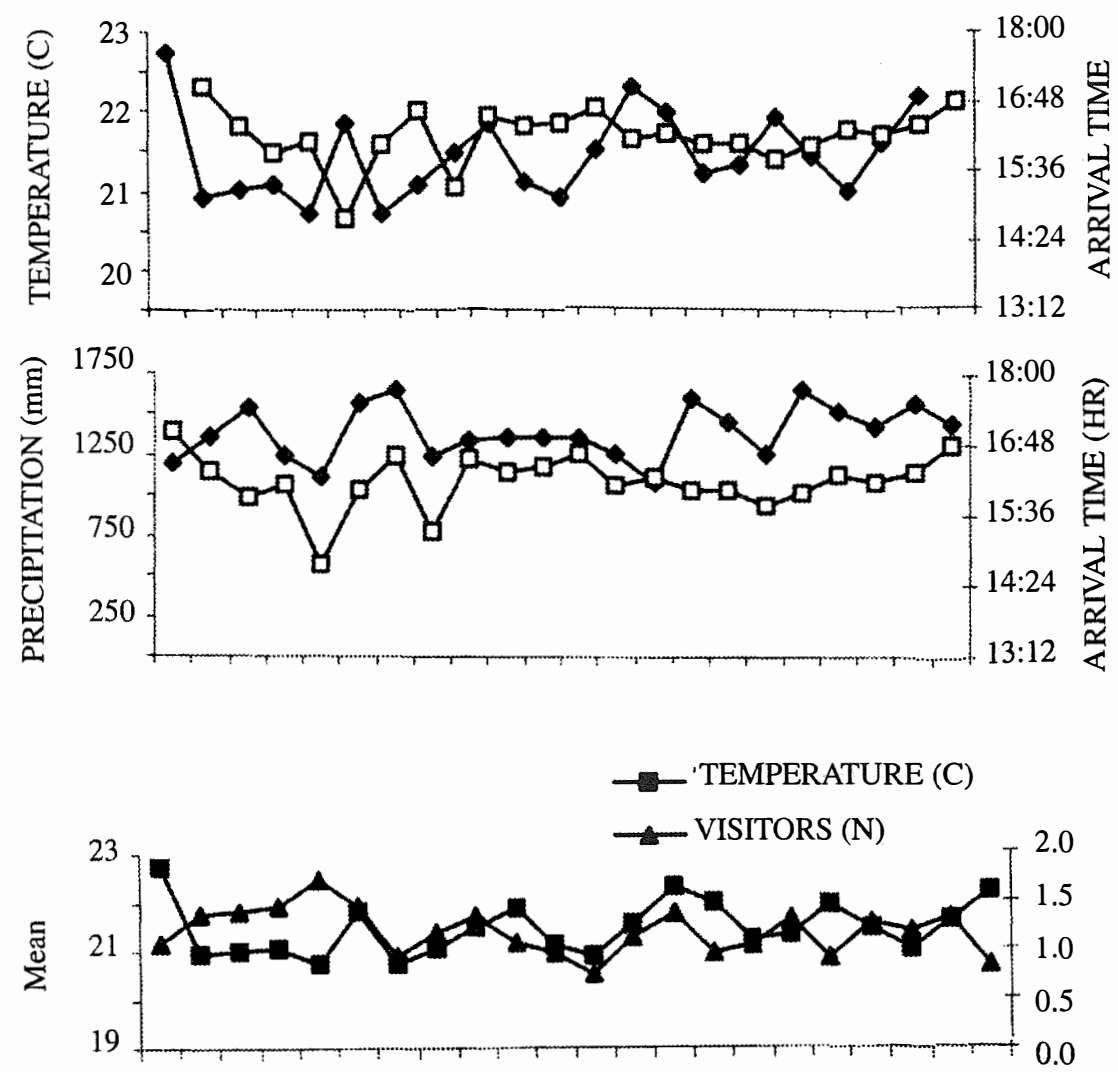

$\rightarrow$ - PRECIPITATION (mm)

$\rightarrow-\operatorname{VISITORS}(\mathrm{N})$

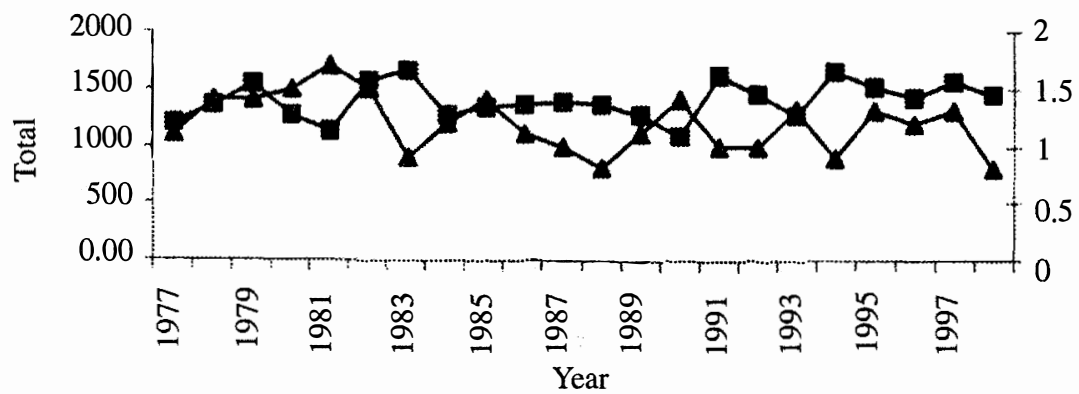

Fig 4. Yearly arrival time and visitation patterns of Vanessa atalanta versus temperature and precipitation in a subropical habitat (statistical values in text). 
predation seen: an individual that flew with difficulty was captured by a bird (Cardinalis cardinalis). Some specimens had missing legs or lacked parts of wings, antennae or proboscis.

Visitation pattern: There are no hostplants on the site. The population is composed of visitors that perch and participate in aerial interactions sensu Bitzer and Shaw (1979). The number of visitors begins to increase in autumn, reaches a peak near the end of winter and decreases almost constantly during the spring and summer (Fig. 2a, 2b). Generally, there are two visitation patterns. Pattern I (1977 to 1985): a marked curve with zero population around October, e.g. Fig. 2a). Pattern II (19861996): a flatter curve with 1-5 months without visitors, e.g. Fig. 2b. Arrival time of first individual to enter the area had the same pattern during the study period, with a soft increase from January through June and a soft decline until December (Julian dates, Figs. $2 b$ and 2 d).

The mean daily number of visitors a particular month was inversely correlated with mean monthly temperature (Spearman Rank Correlation, SRC: $\mathrm{r}=-0.43, \mathrm{p}<0.01, \mathrm{n}=261$ months; mean monthly values for number of visitors and climatic factors were used in this and following tests) and precipitation (SRC: $\mathrm{r}=-0.34, \mathrm{p}<0.01$, $\mathrm{N}=261$ ) (Fig. 3A,C). There were occasional absences of 1-14 days that represented gaps in the general trend mostly during stormy weather (Fig. $2 \mathrm{~A}-\mathrm{D}$, a few represent the rare instances in which observer was absent). Arrival time of the first visitor was positively correlated with mean monthly temperature (SRC: $\mathrm{r}=0.84, \mathrm{p}<0.01$, $\mathrm{N}=238$ ) and with mean monthly precipitation (SRC: $\mathrm{r}=0.49, \mathrm{p}<0.01, \mathrm{~N}=231$ ) (Fig. 3B,D). Total daily number of individuals arriving at the site was associated with a subjective classification of climate (Kruskal-Wallis ANOVA, $\mathrm{p}<0.0001, \mathrm{~N}=5658$ days; mean ranks: 4229 windy, 3152 good climate, 2614 cold, 743 overcast or rainy) but not with arrival time (KruskalWallis ANOVA 1.7, $\mathrm{p}=0.63, \mathrm{~N}=4681$ days).

Yearly mean values were not correlated (SRC values: visitors versus temperature -0.17 , visitors versus precipitation -0.40 ; arrival time versus temperature 0.17 , arrival time versus precipitation 0.02 ; in all cases $\mathrm{N}=22$ years and $\mathrm{p}>0.05$ ). (Fig. 4)
There was no significant difference in number of visitors between El Niño (mean 1.13 visitors/day, standard deviation SD 0.21 , range $0.90-1.50, \mathrm{~N}=11$, years 1977,1978 , 1982, 1983, 1986, 1987 and 1991-1995) and non-El Niño years (mean 1.25, SD 0.28, range $0.80-1.70$ visitors/day).

\section{DISCUSSION}

The migratory routes of $V$. atalanta in North America are poorly known, but a greater number of studies in Europe have shown that the migratory population follows temperature layers (Benvenuti et al. 1996), is subjected to significant wind drift and travels with other species (Hansen 1997); has time-compensated sun orientation, migrates thousands of kilometers, feeds in winter and sometimes reproduces while traveling northward in the warmer part of the year, around June (Baker 1972, 1984, Stefanescu et al. 1996, Hansen 1997, Palmqvist 1998). It is now clear that migrations are bidirectional (Benvenuti et al. 1996) but how the travel information is passed among butterfly generations in general is not known (Pasteur 1984) and future studies of $V$. atalanta should stress this aspect.

In this study, seasonal changes in the number of visitors, with fewer visitors in the moister and warmer months and predominance of fresh individuals from January to June suggest that V. atalanta overwinters in Florida and migrates to northerly regions when high summer temperatures affect Florida (R. Bitzer 2000, pers. comm.). A similar migration from Africa to Europe is known (Larsen 1993). This would fit with the smaller individuals seen from late December to late March: fresher individuals may emerge in Florida as the offspring of the larger butterflies first seen in late October early November. These larger individuals could have migrated from more northerly regions earlier in the fall, according to the parallel migration pattern of $V$. atalanta in Europe described by Larsen (1993) and Benvenuti et al. (1996) (R. Bitzer 2000, pers. comm.). For $V$. 
atalanta temperature is a more important limiting factor than host plant availability (BryantSimon et al. 1997, Maier and Shreeve 1995).

The activity period span in Florida is greater than in the more seasonal climate of Iowa, where $V$. atalanta is active from April to October (Bitzer and Shaw 1979, 1995). The greater number of visitors on windy days suggests that the site was selected because it was surrounded by vegetation and buildings (see Swanson 1998).

The El Niño Migration Model predicts that overpopulation increases butterfly migration to outbreak level during El Niño years (Larsen 1984, Myres 1985). We found no difference in number of visitors for El Niño years, apparently because $V$. atalanta is a regular rather than an outbreak migrator.

The limited temperature range that characterizes sites where $V$. atalanta occurs $(\mathrm{Br}-$ yant-Simon et al. 1997, Maier and Shreeve 1995) and butterflies' inability to fly under heavy rain can explain why individuals arrive at their perching spots later in the hot, rainy months. V. atalanta males establish courtship territories 2-4 hours before sunset (Wiltshire 1997, Bitzer and Shaw 1979, 1995) and use neural motion detectors adapted to great speed (O'Carroll et al. 1996) in aerial interactions (Bitzer and Shaw 1979). Territories have distinct characteristics (sunlit clearings and ridge tops) and are used by different individuals over the years (Bitzer and Shaw 1979, Wiltshire 1997). Despite its methodological difference with previous studies, this study produced the same conclusions about territorial behavior, and also agrees with the ecological model of perching behavior which proposes that perching is associated with relatively high temperature, lekking and long life (Wickman 1992a,b, van Dyck et al. 1997a,b, van Dyck and Matthysen 1998. No data are available regarding the wing color and body proportion elements of the model).

If our results can be generalized (and that will be unknown until more long term intensive studies become available) behavioral studies of butterflies do not suffer from the general impossibility of daily observation for long periods, but at least for small areas, occasional population counts covering less than two weeks are unreliable: even total absence of individuals for such periods can simply represent gaps in the general trend. Furthermore, the analysis of yearly values hid the associations of number of individuals and arrival time with climate that were found when a smaller scale was used. Long term studies based on yearly samplings should be re-evaluated for this aspect.

\section{ACKNOWLEDGMENTS}

We thank Shirley Gregory and Pat Miller for assistance and support, María Isabel González for the statistical analysis, Marisol Rodríguez Pacheco and Ana Araya Anchetta for data digitalization and Royce Bitzer, Department of Entomology, Iowa State University, William Ramírez, Museo de Insectos, Universidad de Costa Rica, Per-Olof Wickman, Dpt. Mathematics and Science, Stockholm Institute of Education and one annonymous reviewer, for suggestions that greatly improved the manuscript.

\section{REFERENCES}

Baker, R.R. 1972. The geographical origin of the British spring individuals of the butterflies Vanessa atalanta (L.) and V. cardui (L.). J. Entomol. (A) 46: 185-196.

Baker, R.R. 1984. The dilemma: when and how to go or stay, p. 279-296. In R.I. Vane-Wright \& P.R. Ackery (eds.). The biology of butterflies. Royal Entomological Society, London.

Benvenuti, S., P. Dall'Antonia \& P. Ioale. 1996. Directional preferences in the autumn migration of the red admiral (Vanessa atalanta). Ethology 102: 177-186

Bitzer, R.J. \& K.C. Shaw. 1979 (1980). Territorial behavior of the Red Admiral, Vanessa atalanta (L.) (Lepidoptera: Nymphalidae). J. Res. Lepid. 18: 36-49. 
Bitzer, R.J. \& K.C. Shaw. 1995. Territorial behavior of the Red Admiral, Vanessa atalanta (Lepidoptera: Nymphalidae). I. The role of climatic factors and early interaction frequency in territorial start time. J. Insect Behav. 8: 47-66.

Bryant-Simon, R., D. Thomas-Chris \& S. Bale-Jeffrey. 1997. Nettle-feeding nymphalid butterflies: Temperature, development and distribution. Ecol. Ent. 22: 390-398.

Calvert, W.H., L.P. Brower \& R.O. Lawton. 1992. Mass flight response of overwintering monarch butterflies (Nymphalidae) to cloud-induced changes in solar radiation intensity in Mexico. J. Lepid. Soc. 46: 97-105.

Daily, G.C., P.R. Ehrlich \& D. Wheye. 1991. Determinants of spatial distribution in a population of the subalpine butterfly Oeneis chrysus. Oecologia 88: 587-596.

Ehrlich, P.R. 1984. The structure and dynamics of butterfly populations, p. 25-40. In R.I. Vane-Wright \& P.R. Ackery (eds.). The biology of butterflies. Royal Entomological Society, London.

Frey, D.K., L.H. Leong, D. Fredericks \& S. Raskowitz. 1992. Clustering patterns of monarch butterflies (Lepidoptera: Danaidae) at two California central coast overwintering sites. Ann. Entomol. Soc. Am. 85: 148-153.

Goulson-D; J. Ollerton \& C. Sluman. 1997. Foraging strategies in the small skipper butterfly, Thymelicus flavus: When to switch? Anim. Behav. 53: 1009-1016

Gutiérrez, D. 1997. Importance of historical factors on species richness and composition of butterfly assemblages (Lepidoptera: Rhopalocera) in a northern Iberian mountain range. J. Biogeogr. 24: 77-88.

Hansen, M.D.D. 1997 Observations on the migrations of the Painted Lady Vanessa cardui (L.) in Denmark in 1996: (Lepidoptera: Nymphalidae). Ent. Meddelelser 65: 165-173.

Harrison, S., D.D. Murphy \& P.R. Ehrlich. 1988. Distribution of the Bay Checkerspot butterfly, Euphydryas editha bayensis: evidence for a metapopulation model. Amer. Nat. 132: 360-382.

Kitahara M. \& K. Fuji. 1997. An island biogeographic approach to the analysis of butterfly community patterns in newly designed parks. Res. Pop. Ecol. (Kyoto) $39: 23-35$

Kozlov, M.V., A.L. Lvovsky \& K. Mikkola. 1997. Abundance of day-flying Lepidoptera along an air pollution gradient in the northern boreal forest zone. Ent. Fennica 7: 137-144
Kunte-Krushnamegh, J. 1997. Seasonal patterns in butterfly abundance and species diversity in four tropical habitats in northern Western Ghats. J. Biosci. Bangalore 22: 593-603.

Larsen, T.B. 1984. Butterflies of Saudi Arabia and its neighbours. Stacey, London, 160 p.

Larsen, T.B. 1993. Butterfly mass transit. Nat. History 102: 30-39.

Maier, C. \& T.G. Shreeve. 1995 (1996). Endothermic heat production in three species of Nymphalidae (Lepidoptera). Nota Lepid. 18: 127-137

Monge-Nájera, J., F. Hernández, M.I. González, J. Soley, J.A. Pochet \& S. Zolla. 1998. Spatial distribution and sound production in five species of cryptic tropical butterflies (Hamadryas, Lepidoptera: Nymphalidae): Implication for the industrial melanism debate. Rev. Biol. Trop. 46:297-330.

Myres, M.T. 1985. A southward return migration of Painted Lady butterflies, Vanessa cardui, over southern Alberta in the fall of 1983, and biometeorological aspects of their outbreaks into North America and Europe. Can. Field-Nat. 99: 147-155.

Nielssen, V. \& J. Monge-Nájera. 1991. A comparison of four methods to evaluate butterfly abundance, using a tropical community. J. Lepid. Soc. 45: 241-243.

Neve, G., L. Mousson \& M. Baguette. 1997. Adult dispersal and genetic structure of butterfly populations in a fragmented landscape. Acta Oecol. 17: 621-626.

Nylin, S. 1997. Seasonal adaptations in butterflies: A story on plasticity. Entom. Tidskrift 117: 1-10

O'Carroll, D.C., N.J. Bidwell, S.B. Laughlin \& E.J. Warrant. 1996 Insect motion detectors matched to visual ecology. Nature 382: 63-66

Pollard, E; \& J-N. Greatorex. 1997. Flight-periods of the small heath butterfly, Coenonympha pamphilus (Linnaeus) (Lepidoptera: Nymphalidae, Satyrinae) on chalk downs and in woodland in southern England. Entom. Gaz. 48: 3-7

Palmqvist, G. 1998. Remarkable records of Macrolepidoptera in Sweden 1997. Entomol Tidskrift 119: 13-27.

Pasteur, G. 1984. Les migrations du monarque, Lepidoptere Danaide. C.R. Soc. Biogéogr. 60: 84.

Peterson, M.A. 1997. Host plant phenology and butterfly dispersal: Causes and consequences of uphill movement. Ecology 78: 167-180. 
Stefanescu, C., M. Lockwood \& M. Cebolla. 1996. The butterfly assemblages of northeastern Spanish wetlands. Nota Lepid. 19: 165-184

Steiner, A. 1991. Unusual flight times of butterflies in 1989 and 1990: Results of the global climatic change? Atalanta 22: 237-244.

Singer, M.C. \& C.D. Thomas, 1997. Evolutionary responses of a butterfly metapopulation to human- and climate-caused environmental variation. Am. Nat. 148 (Suppl.): S9-S39

Srygley, R.B., E.G. Oliveira \& R. Dudley. 1997. Wind drift compensation, flyways, and conservation of diurnal, migrant Neotropical Lepidoptera. Proc. Roy. Soc. Lond. Biol. Sci. 263: 1351-1357

Stekolnikov, A.A. 1992. Dynamics of some Lepidoptera (Hesperioidea, Papilionoidea, Sphingoidea, etc.) fauna of the protected oak forest "forest of the Vorskla" during 50 years of observation. Vestn. St-Peterburg Univ. Ser. 3 Biol. (2): 28-36.

Swanson, H.F. 1998. 20 years of butterfly revelations. E.O. Painter, Winter Park, Florida. 102 p. (Library of Congress LC No. 98090034).

Thomas, J.A. 1984. The conservation of butterflies in temperate countries: past efforts and lessons for the future, p. 333-353. In R.I. Vane-Wright \& P.R. Ackery (eds.). The biology of butterflies. Royal Entomological Society, London.

Thompson, J.N. 1988. Variation in preference and specificity in monophagous and oligophagous swallowtail butterflies. Evolution 42: 118-128.

Tuberville, T.D., P.G. Dudley \& A.J. Pollard. 1996. Responses of invertebrate herbivores to stinging trichomes of Urtica dioica and Laportea canadensis. Oikos 75: 83-88.

Vane-Wright, R.I. \& P.R. Ackery (eds.). 1984. The biology of butterflies. Royal Entomological Society, London. $429 \mathrm{p}$.
Wickman, P.O. 1992a. Mating system of Coenonympha butterflies in relation to longevity. Anim. Behav. 44: 141-148.

Wickman, P.O. 1992b. The influence of temperature on the territorial and mate locating behaviour of the small heath butterfly, Coenonympha pamphilus (1.) (Lepidoptera: Saturidae). Behav. Ecol. Sociobiol. 16: $233-238$

Wickman, P.O., C. Wiklund \& B. Karlsson. 1990. Comparative phenology of four satyrine butterflies inhabiting dry grasslands in Sweden. Holarctic Ecol. 13: 238-346.

Wiltshire, E.P. 1997a. Territorial red admirals: Behaviour of Vanessa atalanta (Lepidoptera, Nymphalidae) in a Berkshire garden during the 1995 heatwave, discussed and compared. Entomologist 116: 5865 .

Wiltshire, E.P. 1997b. Observations of butterfly behavior in 1996 in Berkshire: Interplay between Vanessa atalanta (L.), Cynthia cardui (L.) (Lep.: Nymphalidae) and one gay cat, an (?) alluring predator. Ent. Rec. J. Variat. 109: 255-260.

Van-Dyck, H. \& E. Matthysen. 1998. Thermoregulatory differences between phenotypes in the speckled wood butterfly: Hot perchers and cold patrollers? Oecologia 114: 326-334.

Van-Dyck, H., E. Matthysen \& A.A. Dhondt. 1997a. The effect of wing colour on male behavioural strategies in the speckled wood butterfly. Anim. Behav. 53: 39-51.

Van-Dyck, H., E. Matthysen \& A.A. Dhondt. 1997b. Mate-locating strategies are related to relative body length and wing colour in the speckled wood butterfly Pararge aegeria. Ecol. Ent. 22: 116-120.

Young, A.M. 1983. Egg placement by Phoebis (Pieridae) on Cassia (Leguminosae) "anticipates" the tropical rainy season. J. Lepid. Soc. 37: 313-317.

Editor: José A. Vargas

Received 2-VI-1999. Corrected 25-III-2000.

Accepted 27-IV-2000. 